\title{
Yola Eco-Sentials - A SustainableUniversity-Community Engagement Project
}

\author{
Jelena Zivkovic and Raymond Obindu \\ American University of Nigieria, Yola, Nigeria
}

\begin{abstract}
This paper briefs about the Yola Eco-Sentials, a social enterprise which provides the best quality products made with high expertise ranging from designer bags, shoes, furniture's, accessories made from plarn and eco bricks for building long lasting infrastructures to meet the vast demands for fashionable products and durable building materials geared from recycled manufactured materials. This project is where women from the local community come together to the university campus once a week to learn from each other and to strengthen their relationships. This project is considered as a university-community engagement activity as it contributes for the betterment of the environment and women empowerment. The paper focuses on the impacts of Yola EcoSentials on community engagement includes reference to a person on one or more other persons, which involves the ability of a person to care for others, to empathize, to keep the good of others in mind or caring also to the general public to think.
\end{abstract}

\section{Introduction}

Federal Republic of Nigeria is a state in West Africa. It is by far the most populous country in Africa and tried after years of military dictatorship in its democratization and economic development. Nigeria maintained its rich oil deposits due to corruption so far not allowed for successful poverty reduction. It is a country of great cultural diversity (Arimah, 2001, pp. 114-144). Sick, poor and elderly rely on family support, only government officials benefit public welfare. Low incomes and rapidly growing population and the empty treasury led to the failure of all plans to create a health and pension system (Meagher, 2010).The Adamawa State is a state in northeastern Nigeria, resulting from the division of the former State of Gongola and the majority of the working population is employed in agriculture. Yola is the capital administrative of Adamawa State in Nigeria. It is located to the east of the country, on the river Benue, near the border with Cameroon.

With an estimated 170 million people in 2012, Nigeria is the most populous country in Africa. It accounts for one-sixth of the continent's population on only one thirtieth of its surface (about 3\%). Approximately $50 \%$ of the population lives in urban areas and at least 24 cities have more than one million inhabitants. The variety of customs, languages and traditions of the 250 ethnic groups making up the country gives it a rich diversity (Meagher, 2010).As Africa's Development University, the American University of Nigeria (AUN) is committed to fostering enterprises that provide economic opportunity, protect the environment, and extend their benefits to all members of society. Being a developmental university AUN started this initiative to find a way to involve women particularly women who have no means to provide for themselves. The idea that plastic bags can be turned into something very useful and so with the help of local NGOs, it manages to create out of ordering plastic bags wonderful works of art including handbags, table mats, plate mats and anything you can think of, they make it.AUN teamed with women from five non-Government Organizations that are dedicated to improving the lives of citizens who might otherwise be left behind. These women were trained by a top expert in plarn-based craftsmanship, not only to crochet the artworks you see here, but also to teach others to make the same. AUN takes pride in the fact that every item sold by Yola EcoSentials protects the environment and puts money in the pocket of a needy artist.

\section{Social Enterprises}

Social enterprise is an association which aims to treat or promote a social or environmental challenge using methods and conduct business. The first purpose of a Social enterprise is to promote a social goal, followed by maximizing profits; this differs from the business operator's programs that often focuses on CSR after its goal of maximizing profits, and unlike non-profit institution that his actions no purpose to maximize profit (Arimah, 2001, pp. 114-144).

A central feature of successful social enterprise will be a corresponding increase in revenue growth through promoting its social goal. Social mission penetrate corporate culture and organizational structure of the perception that the existence of the two goals together, socially and economically, guaranteed over time. Socialenterprise being the production cross between associations belongs to the third sector, and commercial companies belonging to the business sector herald the development of a new sector in the socio-economic reality in which we live - the fourth sector. One of the foundations of a world's most familiar social business is a 
recipient of the Nobel Prize for Peace, Dr. Muhammad Yunus who founded the Grameen Bank in 1983 - a business that has become one of the world's largest social businesses (Di Domenico et.al, 2010, pp. 681-703).

For instance in Nigeria HOPE is another social enterprise that aims to allow human trafficking's survivors to enter into an enduring employments and rebuilding their lives. It employs the Nigerian survivors of human trafficking and utilizes that money in providing them educational and professional skills and assist in their social integration.

Critical goals of social enterprises are focused to social welfare, community ownership and profit nondistribution.For example Social goals identified the areas of health, education, poverty eradication, environment or climate (E Ite, 2004, pp. 1-11).Social enterprise pursues a social commitment, which is a separately motivated social action, and is usually based on the principles of volunteerism. This means you invest time and / or money in a project that serves a good cause (charity). In this sense it differs from the economic, political and cultural commitment. Social enterprise also pursues the ideology of social investment which refers to the support of projects and companies which have an ecological and sustainable contribution to society afford.

This support can be both monetary and in the form of services take place. In a broader sense, the term social investment, however, is not to be limited to private contributions, as the extensive literature shows to the term.

\section{Yes (Yola Eco-Sentials)}

AUN teamed with women from five non-Government Organizations that are dedicated to improve the lives of citizens who might otherwise be left behind. These women were trained by a top expert in plarn-based craftsmanship, not only to crochet the artworks, but also to teach others to make the same. Yola Eco Sentials is a just such a venture, created to recycle materials into valuable products. The premier product line consists of crafts made from plarn, which is a yarn that's spun from recycled plastic grocery bags. If not recycled, these bags become a terrific nuisance, polluting land and water, and creating toxic smoke when burned in street side dumps.Yola Eco Sentials is a social enterprise that pursues the primary objectives of creating and empowering jobs for community of women divert wastes from irresponsible disposal and produce value-added products with a promising upside in global markets.

Yola EcoSentials is an idea that is sure to spread in its positive influence and intend to make more products out of recycled materials, and to sell them not only in Nigeria but internationally through retailers and web sites that specialize in socially responsible merchandise. Yola EcoSentials is a new company that provides the best quality products made with high expertise ranging from designer bags, shoes, furniture's, accessories made from plarn and eco bricks for building long lasting infrastructures to meet the vast demands for fashionable products and durable building materials geared from recycled manufactured materials. .We supply materials that can stand the test of time and meet the demands of the commercial market locally and also worldwide. The company is an AUN incubated enterprise. It is also considering tendering trusteeship collaboration with the women empowerment team

Yola EcoSentials will be the first recycling centre in Yola and one of the first in Adamawa state, and also holds exclusive license rights with the American University of Nigeria and Nigeria. Yola EcoSentials will be the first recycling centre in Yola and one of the first in Adamawa state hence a rapid investments from the green world fighters is anticipated to join the organization soon.Yola EcoSentials is a non-profit organization made to recycle waste products and so helping the community and the women development centre. The founders' goal is to help and not to make profit; the products will be bought from the women development center which consists mainly of five women in which two will be elected to represent them as part of Eco Sentials. The top management comprise of all voluntary workers and supervisors for the company that won't be paid in any way

Yola EcoSentials is going to focus primarily on two major products which are Plarn Products and Ecobrics. These two products that form the primary products for the business are going to be the main focus of the business as other products will emerge with time. The plan for the envisaged Yola EcoSentials is an outgrowth of the market research formulated by the environmental expert Professor Charles Reith in collaboration with The American University of Nigeria and the Women's organization who are the main engine gearing toward establishing the enterprise.Early in following its establishment in Yola Nigeria in early September 2012, Yola EcoSentials has attained a rapid growth rate being so young a start.

In response to the growing fashion and building materials market potential of the region, represented by the large expatriate AUN (American University of Nigeria) community, Yola EcoSentials do with recycled materials around the environment to promote environmental sustainability. Its products reflect the very best in environmental prospects, and ensure that every purchase made is crafted a form of recycled product. Yola EcoSentials make services to the community by giving back to the community, the community women are paid to make the waste into high end goods. 


\section{Critical Analysis}

\section{Advantages/Disadvantages}

The products of Yola EcoSentials reflect the very best in environmental and social stewardship. Purchase of these products is crafted from recycled grocery bags that would otherwise smolder in street-side dumps, shortening lives with chemical smoke.Yola EcoSentials products are helping promoting health, education and welfare of Nigerian citizens. This project is where women from the local community come together on the university campus once a week to learn from each other and to strengthen relationships. The women take clean recycled bags that have been collected from waste bins on campus and the women create plarn that is then crocheted into beautiful useful products such as handbags, coasters etc. This project is considered a university-community engagement for the betterment of the environment and women empowerment. Students have helped to coordinate the women, students have prepared a business plan, marketing plan, and students coordinate training and carried out other business related tasks.

Yola EcoSentials encourages women empowerment refers to strategies and actions that focus more to the degree of autonomy and self-determination, to increase in their lives and communities and enable them though their interests own authority that is responsible and self-determined to represent. Empowerment refers not only to the process of empowerment but also to the professional support of the people, their sense of power and lack of influence (powerlessness) and to overcome the organizational freedom and resources to perceive and use. Every sale gives $80 \%$ of the sales price to the working ladies and the rest $20 \%$ are also spend for their training purpose and for buying necessary stuff such as scissors etc.

YES program has brought the women together and this is the biggest social benefit impacted by YES.

The quality of the products can potentially be the biggest disadvantage and may result into product failure because, sometimes low quality products are also produced by low skilled women and hence, the trend does not show consistency and sustainability.

\section{Challenges}

Yola EcoSentials is facing some challenges being a new enterprise and operating in a region like Nigeria where the social environment itself imposes many challenges.

Yola EcoSentials needs to bring in effective management and community awareness to involve more women from community.

Project sustainability is another issue for Yola EcoSentials, and it endeavors to reaches deep to the community to develop better involvement.

Record keeping was the biggest challenge of YES. Although the items and inventory are now traceable and organized, Inventory tracking, product duplication, stock-outs and incomplete transactions may result into haphazard situation like a mistake that has occurred before.Sometimes items are sold at various AUN selling points and record of the item is not in place and it becomes difficult to locate the maker of the products from among the women in the EcoSential project

The marketing of the products is the part to be concerned with because people do not place high demands on products.

Another area of disappointment is the attendance of the women for the Ecosentials meeting. They are not consistent because they are not under any obligation to come.

Another problem is the nylon bags; it has been a problem getting sufficient nylon bags to help execute the project. Although the Sustainability Unit is trying in getting the colors, quality and quantity of nylon bags the women need but it has not been easy.

\section{Reflection}

The paper reflects the concept of community university engagement through an incubated project of AUN with NGOS that is Yola EcoSentials. The above discussion identifies the pros and cons of this social enterprise. The project portrays sustainability. It is about the integration of three areas the social, the economic and the environmental. Being a social enterprise it focuses on the environmental part of sustainability; it is a proposal written to the University on how to improve its environment. The paper reflects that a social enterprise can contribute socially and economically and environmentally to the society and environment as it always dig its foundations into a noble cause.

It portrays the concept of civic engagement which is voluntary, not-for-financial benefits to public welfare -promoting involvement of citizens called to achieve common goals. Community university engagement is a normatively and analytically includes voluntary work, self-help, voluntary social work or voluntary commitment and brings them into a conceptual context. But the project like YES helps women in generating money. Social enterprise is an association which aims to treat or promote a social or environmental challenge using methods and conduct business and promote a social goal. The overall discussion of Social enterprise and YES identifies that a social enterprise plays a significant role in developing a place with least poverty by 
involving the community in such projects and inducing them with skills that is helpful for them and bring up money for them, improving their self determination and acts as a mean of their self-help. Moreover a social enterprise serves for a purpose that is eventually for the betterment of the society. The project of YES has amazing environmental impact which is our first goal is to clean up the environment because nylon bags are non biodegradable and they litter the everywhere and environmentally, it has been achieved up to a greater extent that and have instilled the consciousness in NGO women in a way that anywhere they see waste nylon bags, they pick it up for recycling and that is a good habit. And now the women have been able to make a lot of money from the project. Economically, AUN has empowered the women; most of them use their money to pay their children's school fees and taking care of their homes with their earnings. The project actually created job opportunity for them. Economically, AUN have created jobs for the NGO, for anyone that can acquire perfect skills can always make money out of the YES project.

Putting in a nutshell, community university engagement develops interest, which is calculated according to the daily goals of life of its members and is intertwined in many ways according to each other. This is reinforced by a clear dividing line between us and the others and it promotes the objectives of social betterment and common good. Community university engagement understood a counter-concept to mere individual or group interests within a community.

\section{Recommendations - Changes To Improve Engagement}

Community university engagement has shown be an effective initiative, but requires few changes for improved effectiveness of the program and its sustainability and improving their engagement in the project.

First of all the program should be well marketed in order to attain more stabilize financial and professional support. Attendance should be made mandatory and should be tied up to some incentive, that may even $b$ allocated from their wages for instance percentage of $80 \%$ of every sale $60 \%$ should be non conditional whereas the rest $20 \%$ should tied up to the condition of mandatory attendance.

This will also resolve the issue of low quality products as well, in a way that women will be able to learn skill on daily basis.

Moreover they can be encouraged bringing in more community women and can be rewarded with monetary or non monetary rewards and will bring out leadership qualities in them. It will also help in saving marketing cost of the project through word of mouth marketing by these women.

It is recommended to train one or two women from the community at expert level so that it will be easier to communicate the techniques and procedure. Whilst asking the translator to make them learn a few basic words and sentences in English, so that the communication do not fail in the absence of the translator.

To produce good quality products women should be divided into groups and the task should be divided in team for instance allocating few of them for collecting plastic bags, while few for washing them and the most skilled and expert for crafting them into beautiful nylon bags. This will also improve the product and process efficiency.

Work of these community females should be encouraged in exhibitions to promote it internationally.

Before expanding to future products of crafted jewelry and aluminum crafts women should be bounded to certain quality standards. This will help them understanding the quality criteria.

One or two record keeping personnel should be identified and allocated to protect data and inventory and making it traceable.

Product should be marketed at an improved level and a small tag of Yola EcosSential should be placed at the products to give them a professional look and improving the brand awareness among people of Yola.

For increased community involvement the programs can be marketed among the schools as considered by YES, among housewives and to all those who found it interested.

University personnel should be allocated with a task of promoting project in different areas and bring in more women into the project.

Institutes that are thinking for setting up a social enterprise should ensure that the cause of the project must be well communicated among the community and an effective management plan is prepared with appropriate allocation of human and material resources along with predefined quality standards, record keeping, marketing strategy, effective communication and well defined agenda (Putnam, 1993, pp. 35-42). Their objective must be focused to community engagement which is not limited to material gain directed

(Torres \& Schaffer, 2000). So it is not as gainful employment, paid time-or performance-equivalent and is therefore not primarily due to the payment instead (Enos \& Morton, 2003, pp. 20-41).

\section{Conclusion}

This paper concludes the information about the Yola Eco-Sentials, a social enterprise which provides the best quality products prepared from recycling of waste plastic bags. This project is considered as a university-community engagement activity as it contributes for the betterment of the environment and women 
empowerment. The paper focuses on the impacts of Yola Eco-Sentials on community engagement.The above discussion concludes that the community engagement is associated with the following attributes; The impact and outcomes of community engagement are voluntary and the quality of community engagement is determined by self-organization and self-determination of voluntarily exercised commitment (Watson, 2003). The voluntary nature corresponds to the transformation of community engagement towards motivational less bound commitment, but also restricts accountability and liability and thus partly the benefits (Aslin \& Brown, 2004).

Community engagement is not limited to material gain directed, so it is not as gainful employment, paid timeor performance-equivalent and is therefore not primarily due to the payment instead (Watson, 2007). At least one effect of community engagement must be a positive effect for community involved, so it must respect the common good (Leiderman et.al, 2003). This does not mean that altruistic motives must be at the forefront, as can the motivation for civic engagement has a self-reference, such as self-actualization motives or forms of selfhelp described above (Bringle \& Hatcher, 2002, pp. 503-516).

Community engagement is for public, or takes place in public space, because the public is both important to the advocacy of those involved, creating a culture of recognition and the provision of information for the activities of those involved. On the other hand, it ensures transparency, dialogue, participation and responsibility in the organization forms of engagement (Enos \& Morton, 2003, pp. 20-41).In general, community engagement exercise jointly or cooperative practices. It includes not only the commitment within the meaning of traditional volunteering, which denotes highly formalized, long-term commitment, especially. Public criticism and opposition, as well as other forms of self-organization are also part of exercise, for being there and being against belong equally to citizenship in a democratic polity and make the productivity and innovativeness as observed in case of Yola EcoSentials.

\section{References}

[1]. Arimah, B. C. (2001). Nature and determinants of the linkages between informal and formal sector enterprises in Nigeria. African Development Review, vol.13 no. (1), pp. 114-144.

[2]. Aslin, H., \& Brown, V. (2004). Towards Whole of Community Engagement: a practical toolkit.

[3]. Bringle, R. G., \& Hatcher, J. A. (2002). Campus-community partnerships: The terms of engagement. Journal of Social Issues, vol. 58 no. (3), pp. 503-516.

[4]. Di Domenico, M., Haugh, H., \& Tracey, P. (2010). Social bricolage: Theorizing social value creation in social enterprises. Entrepreneurship theory and practice,vol. 34 no. (4), pp. 681-703.

[5]. E Ite, U. (2004). Multinationals and corporate social responsibility in developing countries: a case study of Nigeria. Corporate Social Responsibility and Environmental Management, vol. 11 no. (1), pp. 1-11.

[6]. Enos, S., \& Morton, K. (2003). Developing a theory and practice of campus-community partnerships. Building partnerships for service-learning, pp. 20-41.

[7]. Leiderman, S., Furco, A., Zapf, J., \& Goss, M. (2003). Building partnerships with college campuses: Community perspectives. A Publication of the Consortium for the Advancement of Private Higher Education's Engaging Communities and Campuses Grant Program. Washington, DC: The Council of Independent Colleges.

[8]. Meagher, K. (2010). Identity economics: social networks \& the informal economy in Nigeria. Boydell \& Brewer Ltd.

[9]. Paton, R. (2003). Managing and measuring social enterprises. Sage.

[10]. Pestoff, V. (1998). Beyond the market and state: social enterprises and civil democracy in a welfare society.

[11]. Putnam, R. D. (1993). The prosperous community. The american prospect, vol. 4 no. (13), pp. 35-42.

[12]. Torres, J., \& Schaffer, J. (2000). Benchmarks for campus/community partnerships. Campus Compact.

[13]. Watson, D. (2003, July). Universities and civic engagement: a critique and a prospectus. In Keynote Address given at the 2nd 'Inside Out'Conference on the Civic Role of Universities, Brighton, UK.

[14]. Watson, D. (2007). Managing civic and community engagement. McGraw-Hill International.

[15]. Watson, D., \& Maddison, E. (2005). Managing Institutional Self Study. McGraw-Hill International.

[16]. Wedgwood, M. (2006). Mainstreaming the third stream. Beyond mass higher education: Building on experience, pp. 134-158. 